\title{
Communication \\ Identification of Bioactive Natural Product from the Stems and Stem Barks of Cornus walteri: Benzyl Salicylate Shows Potential Anti-Inflammatory Activity in Lipopolysaccharide-Stimulated RAW 264.7 Macrophages
}

\author{
Dahae Lee ${ }^{1,2,+}$, Akida Alishir ${ }^{2,+}$, Tae Su Jang ${ }^{3, *}$ and Ki Hyun Kim ${ }^{2, *}$ (D) \\ 1 College of Korean Medicine, Gachon University, Seongnam 13120, Korea; pjsldh@gachon.ac.kr \\ 2 School of Pharmacy, Sungkyunkwan University, Suwon 16419, Korea; akida.alishir@gmail.com \\ 3 College of Medicine, Dankook University, Cheonan 31116, Korea \\ * Correspondence: jangts@dankook.ac.kr (T.S.J.); khkim83@skku.edu (K.H.K.); Tel.: +82-41-550-1476 (T.S.J.); \\ $+82-31-290-7700$ (K.H.K.) \\ + These authors contributed equally to this paper.
}

check for updates

Citation: Lee, D.; Alishir, A.; Jang, T.S.; Kim, K.H. Identification of Bioactive Natural Product from the Stems and Stem Barks of Cornus walteri: Benzyl Salicylate Shows Potential Anti-Inflammatory Activity in Lipopolysaccharide-Stimulated RAW 264.7 Macrophages. Pharmaceutics 2021, 13, 443. https:// doi.org/10.3390/pharmaceutics13040443

Academic Editor: Javier Garcia-Pardo, Maria Camilla Bergonzi and Charles M. Heard

Received: 19 February 2021

Accepted: 23 March 2021

Published: 25 March 2021

Publisher's Note: MDPI stays neutral with regard to jurisdictional claims in published maps and institutional affiliations.

Copyright: $\odot 2021$ by the authors. Licensee MDPI, Basel, Switzerland. This article is an open access article distributed under the terms and conditions of the Creative Commons Attribution (CC BY) license (https:// creativecommons.org/licenses/by/ $4.0 /)$.
Abstract: Cornus walteri (Cornaceae), known as Walter's dogwood, has been used to treat dermatologic inflammation and diarrheal disease in traditional oriental medicine. As part of an ongoing research project to discover natural products with biological activities, the anti-inflammatory potential of compounds from C. walteri in lipopolysaccharide (LPS)-stimulated mouse RAW 264.7 macrophages were explored. Phytochemical analysis of the methanol extract of the stem and stem bark of $C$. walteri led to the isolation of 15 chemical constituents. These compounds were evaluated for their inhibitory effects on the production of the proinflammatory mediator nitric oxide (NO) in LPS-stimulated macrophages, as measured by NO assays. The molecular mechanisms underlying the anti-inflammatory activity were investigated using western blotting. Our results demonstrated that among 15 chemical constituents, lupeol and benzyl salicylate inhibited NO production in LPS-activated RAW 264.7 macrophages. Benzyl salicylate was more efficient than $N^{\mathrm{G}}$-monomethyl-Larginine mono-acetate salt (L-NMMA) in terms of its inhibitory effect. In addition, the mechanism of action of benzyl salicylate consisted of the inhibition of phosphorylation of IKB kinase alpha (IKK $\alpha$ ), I $\mathrm{B}$ kinase beta $(\mathrm{IKK} \beta)$, inhibitor of kappa $\mathrm{B}$ alpha $(\mathrm{I} \kappa \mathrm{B} \alpha)$, and nuclear factor kappa $\mathrm{B}(\mathrm{NF}-\kappa \mathrm{B})$ in LPS-stimulated macrophages. Furthermore, benzyl salicylate inhibited the expression of inducible nitric oxide synthase (iNOS) and cyclooxygenase-2 (COX-2). Taken together, these results suggest that benzyl salicylate present in the stem and stem bark of $C$. walteri has potential anti-inflammatory activity, supporting the potential application of this compound in the treatment of inflammatory diseases.

Keywords: Cornus walteri; cornaceae; inflammation; nitric oxide; nuclear factor kappa B; inducible nitric oxide synthase; cyclooxygenase-2

\section{Introduction}

Inflammatory responses are the biological reactions of body tissues to stimulation by various cytokines secreted by a range of other cells [1]. Macrophages are inflammatory cells that play an important role in the promotion of inflammatory responses by producing nitric oxide (NO) as a proinflammatory mediator [2]. Therefore, the quantities of inflammatory mediators and the activity levels in the signaling pathways that regulate these mediators in macrophages may provide evidence of the effects of anti-inflammatory agents.

As part of an ongoing research project to discover bioactive compounds in diverse natural resources [3-9], we investigated candidate phytochemicals from a methanol extract of the stem and stem bark of Cornus walteri to explore their anti-inflammatory potential by using a mouse macrophage cell line (RAW 264.7). Cornus walteri Wanger, belonging to the 
family Cornaceae, is known as Walter's dogwood. This plant is a deciduous shrub grown in eastern Asia, especially in China and Korea, as an economic crop for high-grade furniture and agricultural tools. Traditionally, its fruits and leaves have been used in folk medicine to treat the dermatologic inflammation caused by lacquer poisoning, as indicated in the Chinese Materia Medica [10]. Its leaves have been also used as a Korean medicine herb to treat diarrhea [11]. Previous pharmacological studies of this plant have reported that C. walteri extracts exhibit therapeutic properties, including anti-hyperglycemic and antiobesity effects and anti-inflammatory and antioxidant properties [12,13]. A recent study revealed that such extracts protect reconstituted human skin against photoaging caused by ultraviolet B (UVB) [10]. In addition, previous chemical investigations of C. walteri have demonstrated the presence of diverse types of chemical constituent, including lignans and flavonoids $[14,15]$. However, few previous studies have been carried out to investigate the chemical constituents of $C$. walteri, despite many studies on the pharmacological effects of C. walteri extracts.

In this context, our group focused on the potentially bioactive constituents of $C$. walteri. In our previous chemical investigation of C. walteri, we identified triterpenoids and $\delta$-valerolactones, which showed cytotoxicity against several human cancer cell lines, using bioassay-guided fractionation of the methanol extract of C. walteri [16-19]. In particular, we found that betulinic acid, a triterpenoid, reduced the viability of A2780 human ovarian carcinoma cells and induced apoptotic cell death through both extrinsic and intrinsic apoptosis pathway [19]. Furthermore, we identified new tirucallane triterpenoids (cornusalterins $\mathrm{N}-\mathrm{P}$ ) in $\mathrm{C}$. walteri, along with bioactive tirucallane triterpenoids that control adipocyte and osteoblast differentiation [20]. A nephroprotective agent has also been identified in C. walteri extracts using a model of cisplatin-induced cell death in LLC-PK1 kidney proximal tubule cell line; it was found to decrease the proteins involved in intrinsic apoptosis pathway [21]. As C. walteri extract has been known to inhibit NO production in RAW 264.7 macrophages stimulated with lipopolysaccharide (LPS) [22], the present study was carried out for further investigation of the methanol extracts of the stem and stem bark of $C$. walteri to identify potential anti-inflammatory constituents. Herein, we describe the isolation and structural characterization of compounds 1-15 and evaluate their anti-inflammatory activity in LPS-stimulated RAW 264.7 macrophages.

\section{Materials and Methods}

\subsection{Plant Material, Extraction and Isolation of Compounds 1-15}

The information for plant material and extraction of the plant is included in Supplementary Materials. The detailed procedure for the isolation of compounds 1-15 is also included in Supplementary Materials.

\subsection{RAW 264.7 Cells Culture}

A mouse macrophage cell line, RAW 264.7 (American Type Culture Collection, Rockville, MD, USA), was cultured in DMEM (Manassas, VA, USA) containing 4 mM L-glutamine, antibiotics ( $1 \%$ penicillin/streptomycin), and 10\% fetal bovine serum in humidified air environment at $37^{\circ} \mathrm{C}$ in a $5 \% \mathrm{CO}_{2}$.

\subsection{Measurement of Viability of RAW 264.7 Cells}

RAW 264.7 cells $\left(3 \times 10^{4}\right.$ cells / well) were exposed to the indicated concentrations of compounds 1-15 for $24 \mathrm{~h}$ at $37^{\circ} \mathrm{C}$ and incubated for an additional $40 \mathrm{~min}$ with Ez-Cytox solution (Daeil Lab Service Co., Seoul, Korea). Optical density at $450 \mathrm{~nm}$ was determined using a spectrophotometer microplate (PowerWave XS; Bio-Tek Instruments, Winooski, VT, USA).

\subsection{Measurement of NO Produced by RAW 264.7 Cells}

RAW 264.7 cells $\left(3 \times 10^{4}\right.$ cells / well $)$ were exposed to the indicated concentrations of compounds 1-15 for $1 \mathrm{~h}$ and then incubated for an additional $24 \mathrm{~h}$ with LPS $(1 \mu \mathrm{g} / \mathrm{mL})$. At 
the end of the incubation, each culture supernatant was blended with the Griess reagent to determine NO production by RAW 264.7 cells. Optical density at $540 \mathrm{~nm}$ of mixture was determined using a spectrophotometer microplate (PowerWave XS; Bio-Tek Instruments, Winooski, VT, USA).

\subsection{Western Blot Analysis}

RAW 264.7 cells $\left(4 \times 10^{5}\right.$ cells / well) were exposed to the indicated concentrations of benzyl salicylate (15) for $1 \mathrm{~h}$ and then incubated for an additional $24 \mathrm{~h}$ with LPS $(1 \mu \mathrm{g} / \mathrm{mL})$. At the end of the incubation, the RAW 264.7 cells were lysed with lysis buffer (Cell Signaling Technology, Beverly, MA, USA), supplemented with $1 \mathrm{mM}$ phenylmethylsulfonyl fluoride, for $20 \mathrm{~min}$. For western blot analysis, $20 \mu \mathrm{g}$ of the total protein from the cell lysate was separated by $10 \%$ sodium dodecyl sulfate-polyacrylamide gel electrophoresis (SDS-PAGE). The proteins were electro-transferred to a polyvinylidene fluoride (PVDF) membrane. Each PVDF membrane was probed with primary antibodies (Cell Signaling Technology, Beverly, MA, USA) overnight, incubated with horse radish peroxidase-conjugated antirabbit antibodies (Cell Signaling, Beverly, MA, USA) for $1 \mathrm{~h}$ at room temperature, and visualized using an enhanced chemiluminescence detection reagent (GE Healthcare, Little Chalfont, UK). Western blot signals were detected by FUSION Solo Chemiluminescence System (PEQLAB Biotechnologie GmbH, Erlangen, Germany).

\subsection{Statistical Analysis}

All assays were performed in triplicate and repeated at least three times. All data are presented as the mean \pm standard deviation (SD). Statistical significance was determined using one-way analysis of variance (ANOVA) and multiple comparisons with the Bonferroni correction. A $p$ value of $<0.05$ indicated statistical significance. All analyses were performed using SPSS Statistics ver. 19.0 (SPSS Inc., Chicago, IL, USA).

\section{Results}

\subsection{Isolation and Identification of the Compounds}

The stem and stem bark of $C$. walteri were extracted with $80 \%$ methanol under reflux to obtain the methanol extract by rotary evaporation. The methanol extract was sequentially partitioned using the organic solvents hexane, $\mathrm{CHCl}_{3}$, and $n$-butanol to yield each solvent fraction (Figure 1). TLC analysis of the solvent fractions determined that the hexane-soluble fraction possesses the major spots. Phytochemical analysis of the hexane fraction was carried out by applying column chromatography and high-performance liquid chromatography (HPLC) as well as LC/MS analysis. Semi-preparative HPLC separation

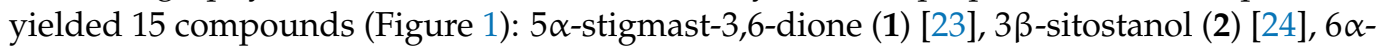
hydroxy- $\beta$-sitostenone (3) [25], 6 $\beta$-hydroxysitostenone (4) [26], norphytan (5) [27], phytone (6) [28], methyl 3-O-acetylbetulinate (7) [29], 3-O-acetylbetulin (8) [30], sitostenone (9) [31], leucophyllone (10) [16], lupeol (11) [32], lupenone (12) [33], betulinic acid (13) [34], betulinic acid methyl ester (14) [35], and benzyl salicylate (15) [36]. The structures of compounds 1-15 (Figure 2) were determined by comparing their ${ }^{1} \mathrm{H}$ and ${ }^{13} \mathrm{C}$ NMR spectra with those previously reported in the literature $[16,23-36]$, and by LC/MS analysis. 


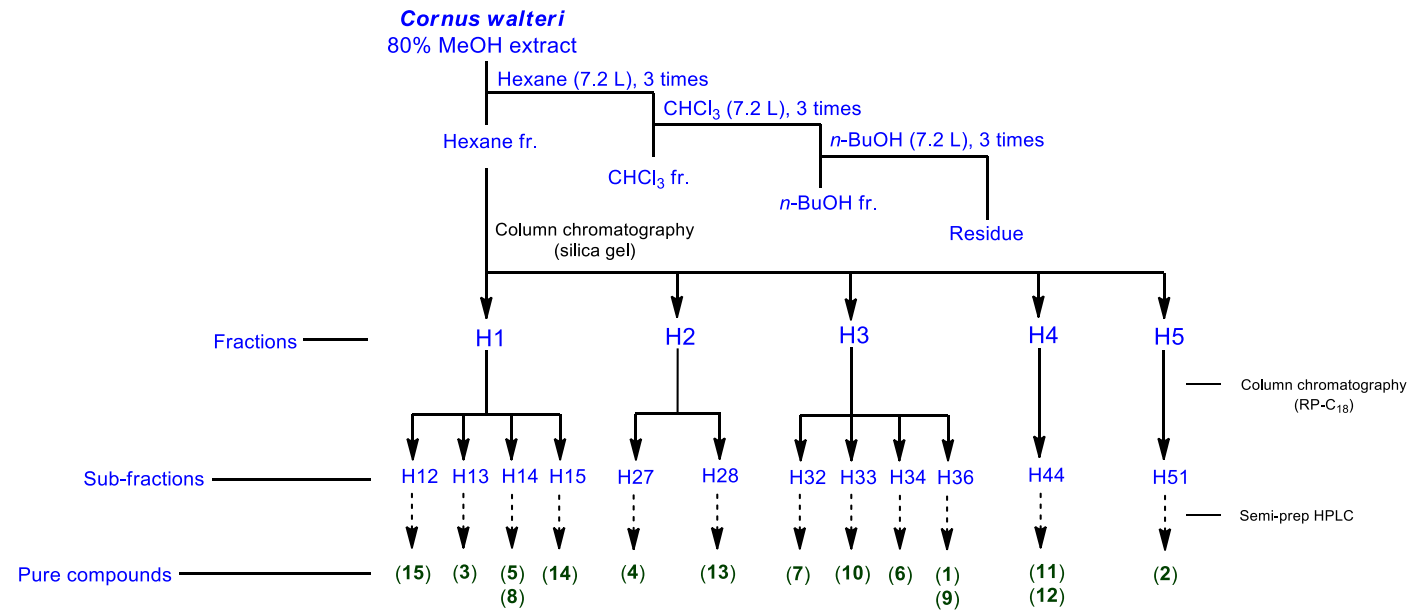

Figure 1. Separation scheme of compounds 1-15. $5 \alpha$-Stigmast-3,6-dione (1), 3 3 -sitostanol (2), $6 \alpha$-hydroxy- $\beta$-sitostenone (3), 6 $\beta$-hydroxysitostenone (4), norphytan (5), phytone (6), methyl 3-O-acetylbetulinate (7), 3-O-acetylbetulin (8), sitostenone (9), leucophyllone (10), lupeol (11), lupenone (12), betulinic acid (13), betulinic acid methyl ester (14), and benzyl salicylate (15). $\mathrm{MeOH}$, methanol; $\mathrm{BuOH}$, butanol; RP, reversed phase; HPLC, high-performance liquid chromatography.<smiles>CCC(CC[C@@H]1CC[C@H]2[C@@H]3CC(=O)C4CC(=O)CC[C@]4(C)[C@H]3CC[C@@]21C)C(C)C</smiles><smiles>CCC(CCC(C)[C@H]1CC[C@H]2C3CCC4CC(O)CCC4(C)C3CCC21C)C(C)C</smiles><smiles>CCC(CC[C@H](C)[C@@H]1CC[C@H]2[C@@H]3C[C@H](O)C4=CC(=O)CC[C@]4(C)[C@H]3C[C@@]12C)C(C)C</smiles><smiles>CCC(CC[C@@H](C)[C@H]1CC[C@H]2C3CC(O)C4=CC(=O)CC[C@]4(C)C3C[C@]21C)C(C)C</smiles><smiles>CC(=O)CCC[C@H](C)CCC[C@@H](C)CCCC(C)C</smiles>

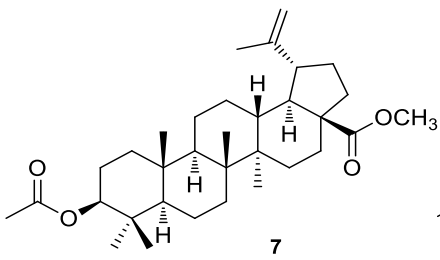<smiles>C=C(C)[C@@H]1CCC2(CO)CC[C@H]3[C@@H]4CC[C@H]5[C@H](C)[C@@H](OC(C)=O)CC[C@]5(C)[C@H]4CC[C@]3(C)[C@H]12</smiles><smiles>CCC(CC[C@@H](C)[C@H]1CC[C@H]2C3CCC4=CC(=O)CC[C@]4(C)[C@H]3CC[C@@]21C)C(C)C</smiles><smiles>COC(C)(C)/C=C/CC(C)[C@H]1CC[C@]2(C)C3=CC[C@H]4[C@@H](C)C(=O)CC[C@]4(C)[C@H]3CC[C@H]12</smiles>

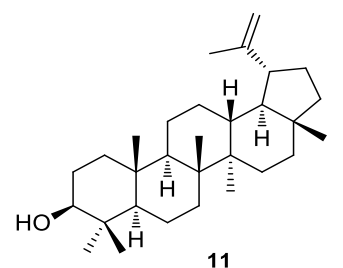<smiles>C=C(C)[C@@H]1CCC2(C)CC[C@]3(C)[C@H]4CC[C@H]5[C@H](C)C(=O)CC[C@]5(C)[C@H]4CC[C@]3(C)[C@H]12</smiles><smiles>C=C(C)C1CCC2(C(=O)O)CC[C@H]3C4CCC5[C@H](C)[C@H](O)CC[C@]5(C)C4CC[C@H]3[C@H]12</smiles><smiles>C=C(C)[C@H]1CCC2(C(=O)OC)CC[C@H]3[C@@H]4CC[C@H]5[C@H](C)[C@@H](O)CC[C@]5(C)[C@H]4CC[C@]3(C)[C@H]12</smiles><smiles>O=C(OCc1ccccc1)c1ccccc1O</smiles>

14 15

Figure 2. Chemical structures of compounds 1-15. $5 \alpha$-Stigmast-3,6-dione (1), 3 $\beta$-sitostanol (2), $6 \alpha$-hydroxy- $\beta$-sitostenone (3), 6ß-hydroxysitostenone (4), norphytan (5), phytone (6), methyl 3-O-acetylbetulinate (7), 3-O-acetylbetulin (8), sitostenone (9), leucophyllone (10), lupeol (11), lupenone (12), betulinic acid (13), betulinic acid methyl ester (14), and benzyl salicylate (15). 


\subsection{Effects of Compounds 1-15 on Nitric Oxide (NO) Production}

The inhibitory effects of compounds 1-15 on NO production in LPS-activated RAW 264.7 macrophages were investigated. Among these compounds, only lupeol (11) and benzyl salicylate (15) attenuated nitrite concentration in LPS-activated RAW 264.7 cells (Figure 3). As shown in Figure 3K, compared with the LPS-only treatment group $(19.81 \pm 0.22 \mu \mathrm{M})$, coincubation with $50 \mu \mathrm{M}$ lupeol (11) and LPS resulted in a $13.26 \pm 0.05 \mu \mathrm{M}$ lower nitrite concentration. As shown in Figure 3O, compared with the LPS-only treatment group $(20.13 \pm 0.66 \mu \mathrm{M})$, coincubation with $50 \mu \mathrm{M}$ benzyl salicylate (15) and LPS produced a $5.74 \pm 0.09 \mu \mathrm{M}$ lower nitrite concentration with an $\mathrm{IC}_{50}$ value of $5.51 \pm 0.39 \mu \mathrm{M}$. As shown in Figure 3P, after coincubation with $50 \mu \mathrm{M}$ of the $N^{\mathrm{G}}$-monomethyl-L-arginine monoacetate salt (L-NMMA) and LPS, the nitrite concentration was found to be $12.91 \pm 0.14 \mu \mathrm{M}$ lower than that in the LPS-only treatment group $(19.16 \pm 0.07 \mu \mathrm{M})$.

(A)

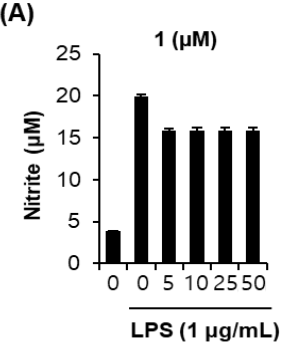

(E)

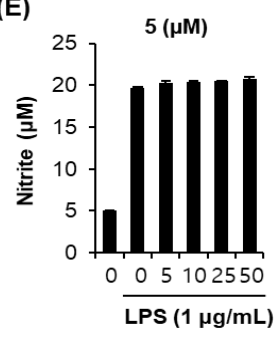

(I)

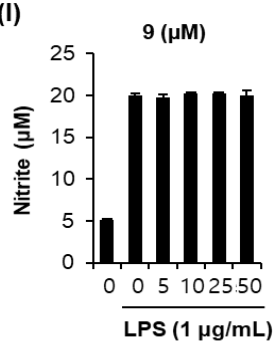

(M)

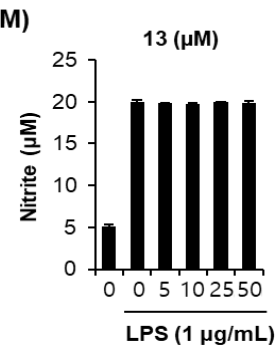

(B)

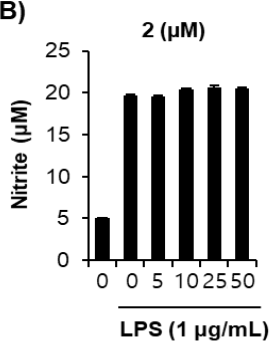

(F)

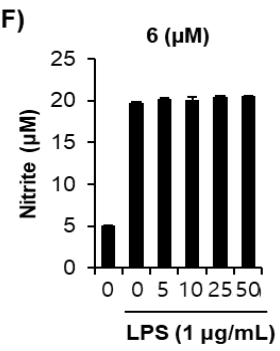

(J)

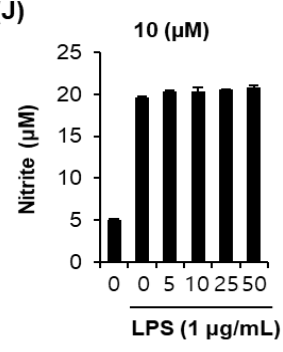

(N)

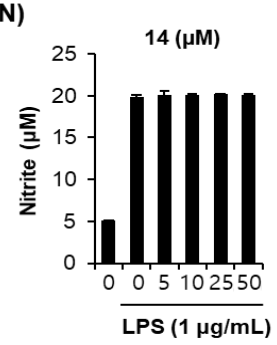

(C)

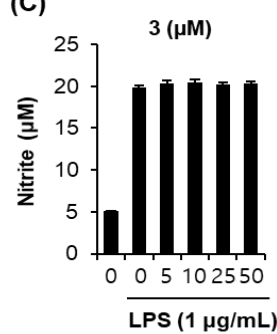

(G)

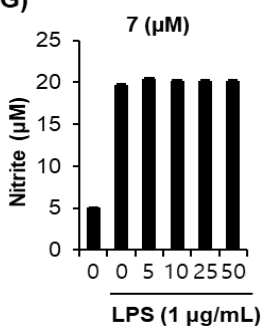

(K)

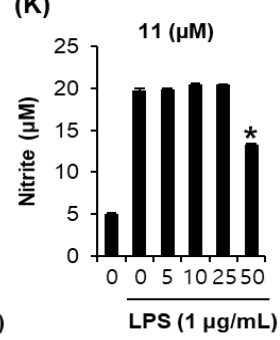

(0)

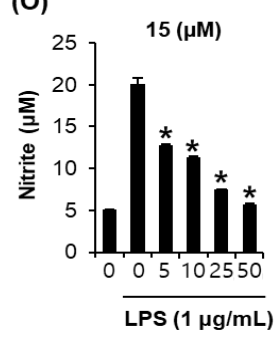

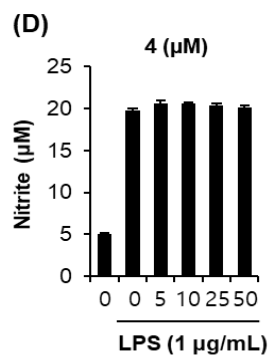

(H)

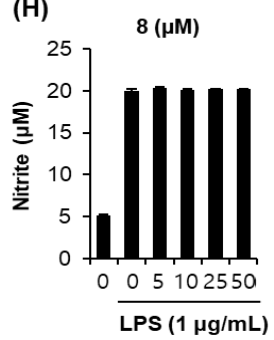

(L)

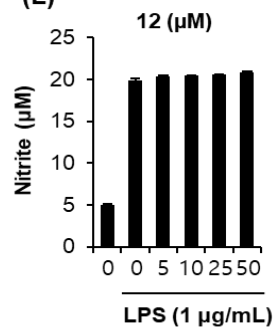

(P)

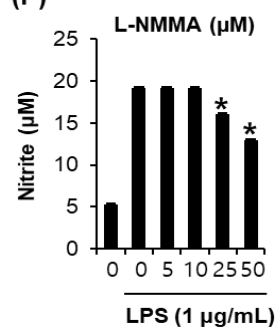

Figure 3. Effects of compounds 1-15 and $N^{\mathrm{G}}$-monomethyl-L-arginine mono-acetate salt (L-NMMA) in RAW 264.7 mouse macrophages treated with lipopolysaccharide (LPS). (A-P) The effects of compounds 1-15 and L-NMMA in RAW 264.7 mouse macrophages treated with LPS were investigated (mean $\pm \mathrm{SD},{ }^{*} p<0.05$ compared to group treated with $1 \mu \mathrm{g} / \mathrm{mL}$ LPS alone). $5 \alpha$-Stigmast-3,6-dione (1), $3 \beta$-sitostanol (2), $6 \alpha$-hydroxy- $\beta$-sitostenone (3), $6 \beta$-hydroxysitostenone (4), norphytan (5), phytone (6), methyl 3-O-acetylbetulinate (7), 3-O-acetylbetulin (8), sitostenone (9), leucophyllone (10), lupeol (11), lupenone (12), betulinic acid (13), betulinic acid methyl ester (14), and benzyl salicylate (15). 
3.3. Effects of Benzyl Salicylate (15) on the LPS-Induced Expression of IKK $\alpha / \beta, I-\kappa B \alpha$, and NF- $\kappa B$ in RAW 264.7 Mouse Macrophages

The effect of benzyl salicylate (15) on LPS-induced expression of IкB kinase alpha and beta $(\mathrm{IKK} \alpha / \beta)$, inhibitor of kappa B alpha $(\mathrm{I}-\mathrm{kB} \alpha)$, and nuclear factor kappa $\mathrm{B}(\mathrm{NF}-\mathrm{kB})$ were analyzed by Western blot. We found that the LPS-stimulated RAW264.7 cells overexpressed $\mathrm{IKK} \alpha / \beta, \mathrm{I}-\mathrm{\kappa} \mathrm{B} \alpha$, and NF- $\mathrm{KB}$, whereas co-incubation with benzyl salicylate (15) inhibited this overexpression (Figure 4 ).

(A)

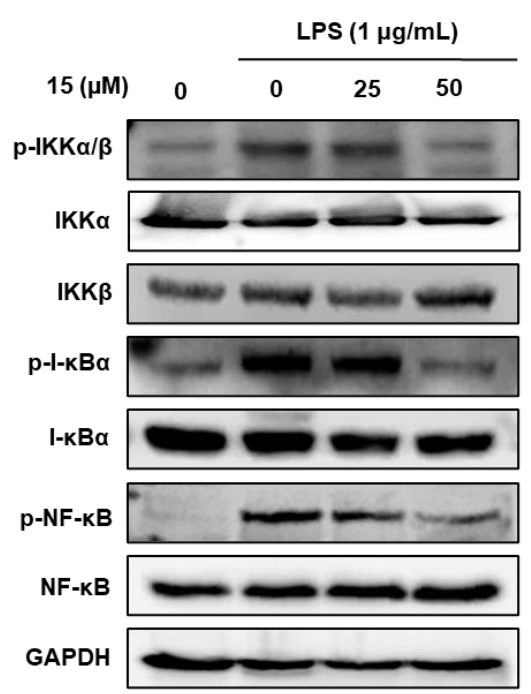

(B)

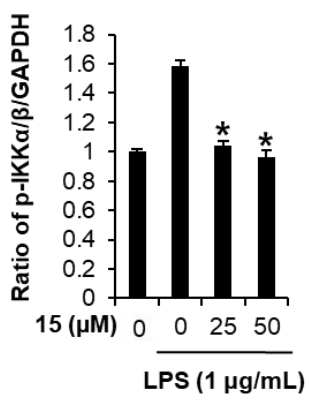

(D)

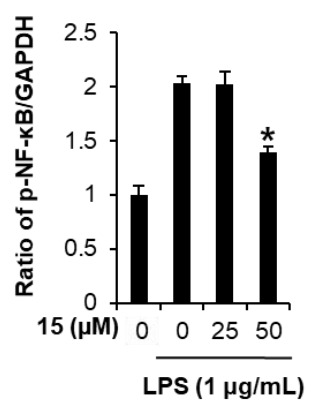

(C)

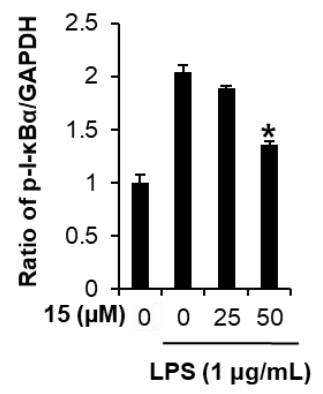

Figure 4. Effects of benzyl salicylate (15) on the expression of IKB kinase alpha and beta (IKK $\alpha / \beta)$, inhibitor of kappa B alpha $(\mathrm{I}-\mathrm{k} B \alpha)$, and nuclear factor kappa B (NF-kB) in RAW 264.7 mouse macrophages treated with lipopolysaccharide (LPS). (A) Representative western blots showing protein expressions of IKK $\alpha / \beta$, phospho-IKK $\alpha / \beta(p-I K K \alpha / \beta), I-\kappa B \alpha$, phospho-IKK $\alpha / \beta$ (p-I- $\kappa \mathrm{B} \alpha)$, NF- $\mathrm{B}$, and glyceraldehyde-3-phosphate dehydrogenase (GAPDH). (B-D) Quantitative bar chart for each protein's expression level (mean $\pm \mathrm{SD},{ }^{*} p<0.05$ compared to group treated with $1 \mu \mathrm{g} / \mathrm{mL}$ LPS alone).

3.4. Effects of Benzyl Salicylate (15) on the LPS-Induced Expression of iNOS and COX-2 in RAW 264.7 Mouse Macrophages

In a subsequent experiment, we found that LPS-stimulated RAW264.7 cells overexpressed iNOS and COX-2, whereas coincubation with benzyl salicylate (15) inhibited this overexpression (Figure 5).

(A)

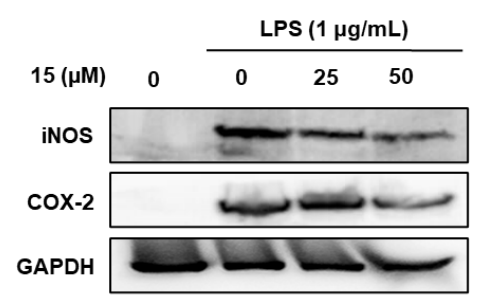

(B)

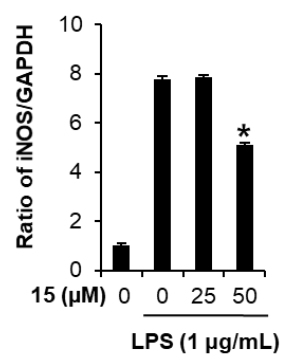

(C)

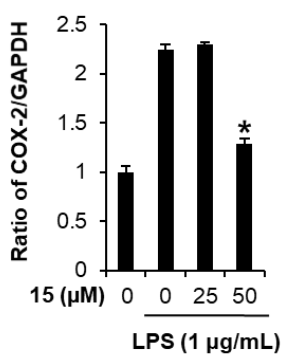

Figure 5. Effects of benzyl salicylate (15) on the expression of inducible nitric oxide synthase (iNOS) and cyclooxygenase-2 (COX-2) in RAW 264.7 mouse macrophages treated with lipopolysaccharide (LPS). (A) Representative western blots showing protein expressions of iNOS, COX-2, and glyceraldehyde-3-phosphate dehydrogenase (GAPDH). (B-C) Quantitative bar chart for each protein's expression level (mean $\pm \mathrm{SD},{ }^{*} p<0.05$ compared to group treated with $1 \mu \mathrm{g} / \mathrm{mL}$ LPS alone). 


\section{Discussion}

In previous study, C. walteri extract has been known to inhibit nitric oxide (NO) production in RAW 264.7 macrophages stimulated with lipopolysaccharide (LPS) [22]. However, little is known about the corresponding bioactive compounds isolated from C. walteri and their possible mechanism of action. Phytochemical analysis in the present study was conducted to isolate the 15 chemical constituents from hexane fraction of the stem and stem bark of $C$. walteri.

Nitric oxide (NO) is synthesized during the inflammatory response to lipopolysaccharide (LPS), an endotoxin; NO production has been extensively used as a model for the study of inflammation in the mouse macrophage cell line RAW 264.7 [37-40]. Overproduction of $\mathrm{NO}$ under abnormal conditions causes an inflammatory response [37-42]. In the present study, the inhibitory effects of compounds $1-15$ on NO production in LPS-activated RAW 264.7 macrophages were investigated [43]. Among these compounds, only lupeol (11) and benzyl salicylate (15) attenuated nitrite concentration in LPS-activated RAW 264.7 cells. Interestingly, benzyl salicylate (15) was more efficient than L-NMMA in inhibiting NO production in LPS-activated RAW 264.7 macrophages. In previous studies, benzyl salicylate was shown to be an active compound with estrogenic activity [44], and a protective agent against cisplatin-induced damage to cells of the LLC-PK1 kidney proximal tubule cell line [21]. However, to the best of our knowledge, there are no reports available regarding the inhibition of NO production in LPS-activated RAW 264.7 macrophages by benzyl salicylate. To investigate the mechanism that inhibits NO production by benzyl salicylate in LPS-activated RAW 264.7 macrophages, western blot analysis was performed.

Upon stimulation by LPS or proinflammatory cytokines, the two catalytic subunits of IKK (IKK $\alpha$ and IKK $\beta$ ) contribute to the phosphorylation of I- $\kappa B \alpha$, which enables the activation of NF- $\mathrm{KB}$ [45]. NF- $\mathrm{KB}$ is a key regulator of the expression of inflammatory cytokines, such as iNOS and COX-2 [46]. In the present study, the LPS-stimulated RAW264.7 cells overexpressed IKK $\alpha / \beta, \mathrm{I}-\kappa \mathrm{B} \alpha$, and NF- $\mathrm{KB}$, whereas co-incubation with benzyl salicylate (15) inhibited this overexpression. Thus, benzyl salicylate (15) inhibited LPS-induced NO production through the inhibition of NF- $\mathrm{KB} / \mathrm{I}-\mathrm{\kappa B} \alpha$ pathway in RAW 264.7 cells.

Activation of NF- $\mathrm{kB}$ increases iNOS expression by increasing its binding to the iNOS promoter to produce NO [47,48]. This simultaneously activates COX-2 synthesis [49]. In the present study, LPS-stimulated RAW264.7 cells overexpressed iNOS and COX-2, whereas coincubation with benzyl salicylate (15) inhibited this overexpression. These findings suggest that benzyl salicylate (15) inhibited LPS-induced NO production by reducing iNOS and COX-2 expression in LPS-stimulated RAW 264.7 cells. Furthermore, they suggest that benzyl salicylate (15) simultaneously inhibited LPS-induced inflammatory responses by blocking the degradation of I- $\mathrm{kB} \alpha$ and thereby inhibiting NF- $\mathrm{kB}$, based on the experimental evidence associated with the inhibition of COX-2 and iNOS expression (Figure 6). Although its bioavailability and bio-accessibility should be verified through additional studies, including animal experiments, our data suggest that benzyl salicylate (15) has potential as an anti-inflammatory agent for the treatment of inflammatory diseases. 

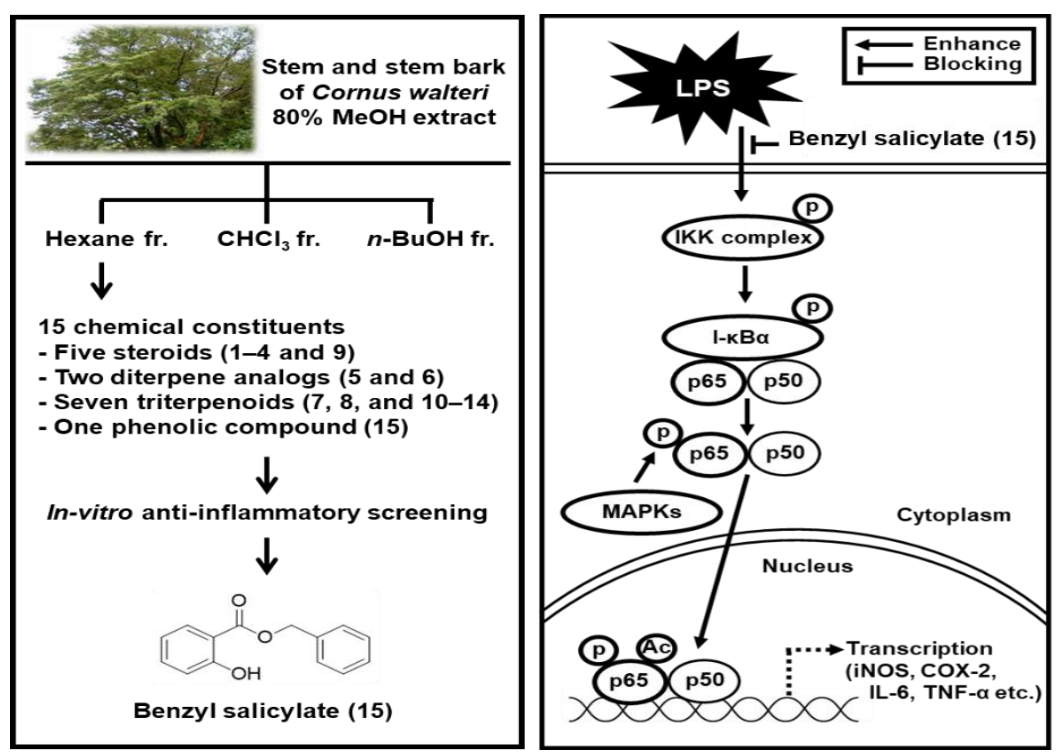

Figure 6. Schematic pathway for the potential role of benzyl salicylate (15) isolated from C. walteri in inflammatory responses. LPS, lipopolysaccharide; p, phosphorylated; IKK, IкB kinase alpha; IкB $\alpha$, inhibitor of kappa B alpha; p56 and p50, cellular proteins; MAPK, mitogen-activated protein kinase; Ac, activated; TNF- $\alpha$, tumor necrosis factor alpha; IL-6, interleukin 6; COX-2, cyclooxygenase-2; iNOS, inducible nitric oxide synthase.

\section{Conclusions}

In this study, we identified fifteen compounds (1-15) present in the stem and stem bark of $C$. walteri. We found that benzyl salicylate (15) inhibited NO production in LPS-stimulated RAW 264.7 macrophages, mediated by inhibition of the expression of the proteins IKK $\alpha / \beta, \mathrm{I}-\kappa \mathrm{B} \alpha, \mathrm{NF}-\mathrm{kB}$, iNOS, and COX-2, which eventually produce NO. Based on these findings, we conclude that benzyl salicylate (15) possesses potential antiinflammatory effects, supporting the application of this compound in the treatment of inflammatory diseases.

Supplementary Materials: The following are available online at https:/ /www.mdpi.com/1999-4 923/13/4/443/s1, General experimental procedure, plant material, and extraction and isolation procedures.

Author Contributions: Conceptualization, T.S.J. and K.H.K.; formal analysis, D.L. and A.A.; investigation, D.L. and A.A.; writing—original draft preparation, D.L., A.A., and K.H.K.; writing-review and editing, K.H.K.; visualization, D.L. and A.A.; supervision, T.S.J. and K.H.K.; project administration, T.S.J. and K.H.K.; funding acquisition, T.S.J. and K.H.K. All authors have read and agreed to the published version of the manuscript.

Funding: This work was supported by a grant from the National Research Foundation of Korea (NRF), funded by the Korean government (MSIT) (grant number: 2019R1A5A2027340 and 2021R1A2C2007937). This research was also supported by the Ministry of Trade, Industry, and Energy (MOTIE), Korea Institute for Advancement of Technology (KIAT), through the Program for Smart Specialization of Infrastructure Construction.

Institutional Review Board Statement: Not applicable

Informed Consent Statement: Not applicable

Conflicts of Interest: The authors declare no conflict of interest. 


\section{References}

1. Chen, L.; Deng, H.; Cui, H.; Fang, J.; Zuo, Z.; Deng, J.; Li, Y.; Wang, X.; Zhao, L. Inflammatory responses and inflammationassociated diseases in organs. Oncotarget 2018, 9, 7204-7218. [CrossRef]

2. Muniandy, K.; Gothai, S.; Badran, K.M.H.; Kumar, S.S.; Esa, N.M.; Arulselvan, P. Suppression of Proinflammatory Cytokines and Mediators in LPS-Induced RAW 264.7 Macrophages by Stem extract of Alternanthera sessilis via the Inhibition of the NF- $\mathrm{kB}$ Pathway. J. Immunol. Res. 2018, 2018, 3430684. [CrossRef]

3. Lee, S.; Lee, D.; Ryoo, R.; Kim, J.C.; Park, H.B.; Kang, K.S.; Kim, K.H. Calvatianone, a Sterol Possessing a 6/5/6/5-Fused Ring System with a Contracted Tetrahydrofuran B-Ring, from the Fruiting Bodies of Calvatia nipponica. J. Nat. Prod. 2020, 83, $2737-2742$. [CrossRef]

4. Lee, S.R.; Kang, H.S.; Yoo, M.J.; Yi, S.A.; Beemelmanns, C.; Lee, J.C.; Kim, K.H. Anti-adipogenic Pregnane Steroid from a Hydractinia-associated Fungus, Cladosporium sphaerospermum SW67. Nat. Prod. Sci. 2020, 26, 230-235.

5. Lee, S.; Ryoo, R.; Choi, J.H.; Kim, J.H.; Kim, S.H.; Kim, K.H. Trichothecene and tremulane sesquiterpenes from a hallucinogenic mushroom Gymnopilus junonius and their cytotoxicity. Arch. Pharm. Res. 2020, 43, 214-223. [CrossRef] [PubMed]

6. Trinh, T.A.; Park, E.J.; Lee, D.; Song, J.H.; Lee, H.L.; Kim, K.H.; Kim, Y.; Jung, K.; Kang, K.S.; Yoo, J.E. Estrogenic Activity of Sanguiin H-6 through Activation of Estrogen Receptor $\alpha$ Coactivator-binding Site. Nat. Prod. Sci. 2019, 25, 28-33. [CrossRef]

7. Ha, J.W.; Kim, J.; Kim, H.; Jang, W.; Kim, K.H. Mushrooms: An Important Source of Natural Bioactive Compounds. Nat. Prod. Sci. 2020, 26, 118-131.

8. Yu, J.S.; Li, C.; Kwon, M.; Oh, T.; Lee, T.H.; Kim, D.H.; Ahn, J.S.; Ko, S.K.; Kim, C.S.; Cao, S.; et al. Herqueilenone A, a unique rearranged benzoquinone-chromanone from the hawaiian volcanic soil-associated fungal strain Penicillium herquei FT729. Bioorg. Chem. 2020, 105, 104397. [CrossRef]

9. Yu, J.S.; Park, M.; Pang, C.; Rashan, L.; Jung, W.H.; Kim, K.H. Antifungal Phenols from Woodfordia uniflora Collected in Oman. J. Nat. Prod. 2020, 83, 2261-2268. [CrossRef] [PubMed]

10. Park, H.C.; Jung, T.K.; Kim, M.J.; Yoon, K.S. Protective effect of Cornus walteri Wangerin leaf against UVB irradiation induced photoaging in human reconstituted skin. J. Ethnopharmacol. 2016, 193, 445-449. [CrossRef]

11. Choi, W.H.; Park, W.Y.; Hwang, B.Y.; Oh, G.J.; Kang, S.J.; Lee, K.S.; Ro, J.S. Phenolic Compounds from the Stem Bark of Cornus walteri Wanger. Korean J. Pharmacogn. 1998, 29, 217-224.

12. Lee, S.H.; Yoon, K.R.; Lee, E.; Cha, Y.Y. Anti-Inflammatory Effect of Cornus walteri. J. Physiol. Pathol. Korean Med. 2011, 25, 982-988.

13. Park, W.H.; Cha, Y.Y. Effects of Stem Bark Extracts of Cornus walteri Wanger on the Lipid Lowering, Anti-oxidative Activity and Concentration of Proinflammatory Cytokines in Rat Fed High Fat Diet. J. Korean Med. Rehabi. 2009, 19, 59-78.

14. Lee, D.Y.; Yoo, K.H.; Chung, I.S.; Kim, J.Y.; Chung, D.K.; Kim, D.K.; Kim, S.H.; Baek, N.I. A new lignan glycoside from the fruits of Cornus kousa Burg. Arch. Pharm. Res. 2008, 31, 830-833. [CrossRef] [PubMed]

15. Vareed, S.K.; Schutzki, R.E.; Nair, M.G. Lipid peroxidation, cyclooxygenase enzyme and tumor cell proliferation inhibitory compounds in Cornus kousa fruits. Phytomedicine 2007, 14, 706-709. [CrossRef] [PubMed]

16. Kim, K.H.; Choi, S.U.; Kim, Y.C.; Lee, K.R. Tirucallane Triterpenoids from Cornus walteri. J. Nat. Prod. 2011, 74, 54-59. [CrossRef] [PubMed]

17. Kim, K.H.; Shin, Y.J.; Choi, S.U.; Lee, K.R. New Cytotoxic $\delta$-Valerolactones from Cornus walteri. Bull. Korean Chem. Soc. 2011, 32, 2443-2445. [CrossRef]

18. Lee, S.R.; Nam, J.W.; Kim, K.H. New Triterpenoids from the stems of Cornus walteri. Chem. Pharm. Bull. 2017, 65, 683-686. [CrossRef]

19. Lee, D.; Lee, S.R.; Kang, K.S.; Ko, Y.; Pang, C.; Yamabe, N.; Kim, K.H. Betulinic Acid Suppresses Ovarian Cancer Cell Proliferation through Induction of Apoptosis. Biomolecules 2019, 9, 257. [CrossRef]

20. Lee, S.R.; Choi, E.; Jeon, S.H.; Zhi, X.Y.; Yu, J.S.; Kim, S.H.; Lee, J.; Park, K.M.; Kim, K.H. Tirucallane Triterpenoids from the Stems and Stem Bark of Cornus walteri that Control Adipocyte and Osteoblast Differentiations. Molecules 2018, 23, 2732. [CrossRef]

21. Lee, D.; Lee, S.R.; Kang, K.S.; Kim, K.H. Benzyl salicylate from the stems and stem barks of Cornus walteri as a nephroprotective agent against cisplatin-induced apoptotic cell death in LLC-PK1 cells. RSC Adv. 2020, 10, 5777-5784. [CrossRef]

22. Yang, E.J.; Yim, E.Y.; Song, G.; Kim, G.O.; Hyun, C.G. Inhibition of nitric oxide production in lipopolysaccharide-activated RAW 264.7 macrophages by Jeju plant extracts. Interdiscipl. Toxicol. 2009, 2, 245-249. [CrossRef]

23. Zhang, D.D.; Yang, J.; Luo, J.F.; Li, X.N.; Long, C.L.; Wang, Y.H. New aporphine alkaloids from the aerial parts of Piper semiimmersum. J. Asian Nat. Prod. Res. 2018, 20, 734-743. [CrossRef] [PubMed]

24. Arai, Y.; Hattori, T.; Hamaguchi, N.; Masuda, K.; Takano, A.; Shiojima, K. Fern Constituents: Dryocrassyl Formate, Sitostanyl Formate and 12 $\alpha$-Hydroxyfern-9(11)-ene from Cyathea podophylla. Chem. Pharm. Bull. 2003, 51, 1311-1313. [CrossRef] [PubMed]

25. Wang, L.K.; Zheng, C.J.; Li, X.B.; Chen, G.Y.; Han, C.R.; Chen, W.H.; Song, X.P. Two New Lanostane Triterpenoids from the Branches and Leaves of Polyalthia obliqua. Molecules 2014, 19, 7621-7628. [CrossRef]

26. Della Greca, M.; Monaco, P.; Previtera, L. Stigmasterols from Typha latifolia. J. Nat. Prod. 1990, 53, 1430-1435. [CrossRef]

27. Dalling, D.K.; Pugmire, R.J.; Grant, D.M.; Hull, W.E. The use of high-field carbon-13 NMR spectroscopy to characterize chiral centers in isopranes. Magn. Reson. Chem. 1986, 24, 191-198. [CrossRef]

28. Zhao, L.; Jin, C.; Mao, Z.; Gopinathan, M.B.; Rehder, K.; Brinton, R.D. Design, Synthesis, and Estrogenic Activity of a Novel Estrogen Receptor Modulator-A Hybrid Structure of $17 \beta$-Estradiol and Vitamin E in Hippocampal Neurons. J. Med. Chem. 2007, 50, 4471-4481. [CrossRef] 
29. Urban, M.; Sarek, J.; Klinot, J.; Hajduch, M. Synthesis of A-Seco Derivatives of Betulinic Acid with Cytotoxic Activity. J. Nat. Prod. 2004, 67, 1100-1105. [CrossRef]

30. Santos, R.C.; Salvador, J.A.R.; Marin, S.; Cascante, M. Novel semisynthetic derivatives of betulin and betulinic acid with cytotoxic activity. Bioorg. Med. Chem. 2009, 17, 6241-6250. [CrossRef]

31. Prachayasittikul, S.; Suphapong, S.; Worachartcheewan, A.; Lawung, R.; Ruchirawat, S.; Prachayasittikul, V. Bioactive Metabolites from Spilanthes acmella Murr. Molecules 2009, 14, 850-867. [CrossRef]

32. Fotie, J.; Bohle, D.S.; Leimanis, M.L.; Georges, E.; Rukunga, G.; Nkengfack, A.E. Lupeol Long-Chain Fatty Acid Esters with Antimalarial Activity from Holarrhena floribunda. J. Nat. Prod. 2006, 69, 62-67. [CrossRef] [PubMed]

33. Puapairoj, P.; Naengchomnong, W.; Kijjoa, A.; Pinto, M.M.; Pedro, M.; Nascimento, M.S.J.; Silva, A.M.S.; Herz, W. Cytotoxic Activity of Lupane-Type Triterpenes from Glochidion sphaerogynum and Glochidion eriocarpum Two of which Induce Apoptosis. Planta Med. 2005, 71, 208-213. [CrossRef] [PubMed]

34. Sholichin, M.; Yamasaki, K.; Kasai, R.; Tanaka, O. Carbon-13 Nuclear Magnetic Resonance of Lupane-Type Triterpenes, Lupeol, Betulin and Betulinic Acid. Chem. Pharm. Bull. 1980, 28, 1006-1008. [CrossRef]

35. Pohjala, L.; Alakurtti, S.; Ahola, T.; Yli-Kauhaluoma, J.; Tammela, P. Betulin-Derived Compounds as Inhibitors of Alphavirus Replication. J. Nat. Prod. 2009, 72, 1917-1926. [CrossRef]

36. Talzi, V.P. A ${ }^{13} \mathrm{C}$ and ${ }^{1} \mathrm{H}$ NMR analysis of perfumes. Russ. J. Appl. Chem. 2006, 79, 107-116. [CrossRef]

37. Li, F.; Cao, Y.; Luo, Y.; Liu, T.; Yan, G.; Chen, L.; Ji, L.; Wang, L.; Chen, B.; Yaseen, A.; et al. Two new triterpenoid saponins derived from the leaves of Panax ginseng and their antiinflammatory activity. J. Ginseng Res. 2019, 43, 600-605. [CrossRef] [PubMed]

38. Coleman, J.W. Nitric oxide in immunity and inflammation. Int. Immunopharmacol. 2001, 1, 1397-1406. [CrossRef]

39. Saba, E.; Lee, Y.Y.; Kim, M.; Hyun, S.H.; Park, C.K.; Son, E.; Kim, D.S.; Kim, S.D.; Rhee, M.H. A novel herbal formulation consisting of red ginseng extract and Epimedium koreanum Nakai-attenuated dextran sulfate sodium-induced colitis in mice. $J$. Ginseng Res. 2020, 44, 833-842. [CrossRef] [PubMed]

40. Xin, C.; Quan, H.; Kim, J.M.; Hur, Y.H.; Shin, J.Y.; Bae, H.B.; Choi, J.I. Ginsenoside Rb1 increases macrophage phagocytosis through p38 mitogen-activated protein kinase/Akt pathway. J. Ginseng Res. 2019, 43, 394-401. [CrossRef]

41. Li, J.; Wang, R.F.; Zhou, Y.; Hu, H.J.; Yang, Y.B.; Yang, L.; Wang, Z.T. Dammarane-type triterpene oligoglycosides from the leaves and stems of Panax notoginseng and their antiinflammatory activities. J. Ginseng Res. 2019, 43, 377-384. [CrossRef]

42. Sharma, J.N.; Al-Omran, A.; Parvathy, S.S. Role of nitric oxide in inflammatory diseases. Inflammopharmacology 2007, 15, 252-259. [CrossRef]

43. Jo, M.S.; Lee, S.; Yu, J.S.; Baek, S.C.; Cho, Y.C.; Kim, K.H. Megastigmane Derivatives from the Cladodes of Opuntia humifusa and Their Nitric Oxide Inhibitory Activities in Macrophages. J. Nat. Prod. 2020, 83, 684-692. [CrossRef]

44. Charles, A.K.; Darbre, P.D. Oestrogenic activity of benzyl salicylate, benzyl benzoate and butylphenylmethylpropional (Lilial) in MCF7 human breast cancer cells in vitro. J. Appl. Toxicol. 2009, 29, 422-434. [CrossRef]

45. Schulze-Osthoff, K.; Ferrari, D.; Riehemann, K.; Wesselborg, S. Regulation of NF-kB Activation by MAP Kinase Cascades. Immunobiology 1997, 198, 35-49. [CrossRef]

46. Tak, P.P.; Firestein, G.S. NF-kB: A key role in inflammatory diseases. J. Clin. Investig. 2001, 107, 7-11. [CrossRef] [PubMed]

47. Jia, J.; Liu, Y.; Zhang, X.; Liu, X.; Qi, J. Regulation of iNOS Expression by NF-кB in Human Lens Epithelial Cells Treated with High Levels of Glucose. Investig. Ophthalmol. Vis. Sci. 2013, 54, 5070-5077. [CrossRef] [PubMed]

48. Murakami, A.; Ohigashi, H. Targeting NOX, INOS and COX-2 in inflammatory cells: Chemoprevention using food phytochemicals. Int. J. Cancer 2007, 121, 2357-2363. [CrossRef]

49. Rahman, M.A.; Dhar, D.K.; Yamaguchi, E.; Maruyama, S.; Sato, T.; Hayashi, H.; Ono, T.; Yamanoi, A.; Kohno, H.; Nagasue, N. Coexpression of Inducible Nitric Oxide Synthase and COX-2 in Hepatocellular Carcinoma and Surrounding Liver: Possible Involvement of COX-2 in the Angiogenesis of Hepatitis C Virus-positive Cases. Clin. Cancer Res. 2001, 7, 1325-1332. 